\title{
Pre-operative length of history and tumour size in central and peripheral bronchial carcinomata
}

\author{
A. K. GUPT A, D. M. PR Y CE, AN D W. K. B LENKINSOP P \\ From St. Mary's Hospital, London, W.2, and Harefield Hospital, Harefield, Middlesex
}

One of the authors has long been interested in the contrasting features of central and peripheral carcinomata of the lung. In a previous paper (Walter and Pryce, 1955b) data were presented concerning the well-known size difference in resected specimens. The present paper deals with the size difference when symptoms begin.

\section{PATHOLOGICAL MATERIAL}

The surgical lung tumours in our storage tanks were re-examined and separated when possible according to the site of origin. There were 110 definite peripheral tumours and 65 definite central tumours available for study. Twenty-nine tumours were oat-cell carcinomata (16 peripheral and 13 central), 35 adenocarcinomata (all peripheral), 90 squamous carcinomata (40 peripheral and 50 central), and 21 polygonal-cell carcinomata (all but two peripheral). The histological classification used was that of Walter and Pryce (1955a).

Cases of bronchial 'adenoma' and specimens in which the site could not be clearly identified were excluded. The possibility of the tumours being metastatic was a clinical consideration before resection but was also borne in mind during the pathological examination.

\section{CLINICAL DATA}

These were obtained from a study of the clinical notes. The pre-operative period was recorded in months from the first symptom. Except for fever, only pulmonary symptoms were considered: neuropathy, arthropathy, and general wasting were noted in some cases but were not analysed.

Twenty-five of the 110 patients with peripheral tumours were without symptoms and the percentage of symptoms in the peripheral group was therefore based on the 85 patients with symptoms. Symptoms were present in all the 65 patients with central tumours.

Haemoptysis was the presenting symptom in $29 \%$ of central cases and in $22 \%$ of peripheral cases. The frequency of an acute febrile onset was $\stackrel{\text { or }}{\omega}$ similar (28\% and $22 \%)$. Dyspnoea was over three $\bigodot_{\infty}$ times as frequent in the central cases $(23 \%$ com- 0 pared with $7 \%$ ). The only symptom which was less frequent in the central group was pain (present $c)$ in $23 \%$ of central cases and in $36 \%$ of peripheral $\frac{\mathbb{O}}{0}$ cases). The most frequent presenting symptom was $\overrightarrow{\mathbb{D}}$ cough (recorded in $48 \%$ of central and $35 \%$ of peripheral cases). This symptom often accom- Q panied other presenting symptoms (in $29 \%$ of $\vec{\bullet}$ central and $18 \%$ of peripheral cases). Cough alone or was the presenting symptom in $17 \%$ of central and $19 \%$ of peripheral cases. It was sometimes difficult to decide in cases of chronic bronchitis when symptoms referable to the tumour began. Chronic bronchitis was recorded in $20 \%$ of central $\frac{\circ}{\mathbb{D}}$ and in $28 \%$ of peripheral cases with symptoms. Thirty-two per cent. of the asymptomatic patients with peripheral tumours were chronic bronchitics.

It is appreciated that clinical information of this kind is based on hearsay evidence, but it was obtained without knowledge of the grouping and it is probable that any errors would be equally distributed.

\section{RESULTS}

These are presented in Tables I and II and in the scatter diagrams (Figs 1 and 2). It should be noted that, owing to the scarcity of adeno- and polygonal-cell carcinomata as central tumours, $\frac{D}{O}$ comparisons between central and peripheral tumours of the same histological type are only $N$ possible with the oat-cell and squamous $N$ carcinomata.

Figure 1 gives the distribution of the $85 \mathrm{~W}$ symptomatic peripheral tumours, plotting the size of tumour against the length of history. It shows $\stackrel{O}{工}$ a tendency for the history to be longer with an $\mathbb{D}$ increase of tumour size, but for the largest ${ }_{+}^{+}$ tumours to have a somewhat shorter history. The ${ }_{0}^{\circ}$ squamous tumours tend to have longer histories than the other two histological types.

Figure 2 shows the distribution of the 65 central $\stackrel{\unrhd}{\varrho}$ tumours. The histories in some cases are very 

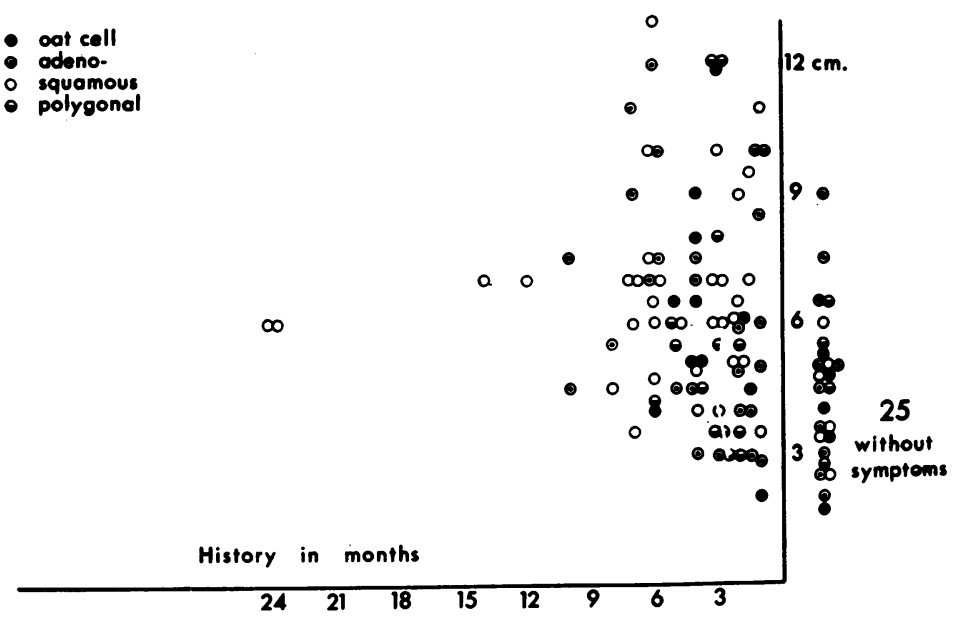

FIG. 1. Distribution of 85 symptomatic peripheral tumours according to size and length of history.

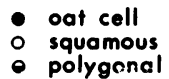

FIG. 2. Distribution of 65 central tumours according to size and length of history.

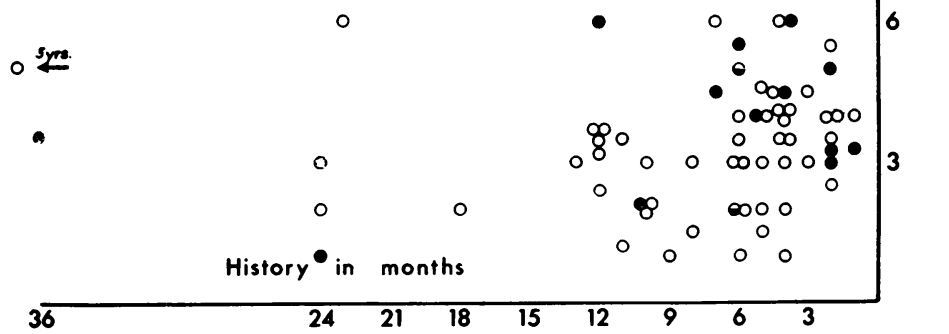

long: five years for one squamous tumour, one, two, and even three years for three oat-cell tumours.

The scatter diagrams clearly show the longer operability of the peripheral tumours. Central tumours become inoperable at about $6 \mathrm{~cm}$. diameter. Some peripheral tumours, on the other hand, remain resectable till twice this size. Small tumours are much more numerous in the central group. Thus in the range 0 to $2 \mathrm{~cm}$. there are 16 central tumours to one peripheral tumour.

The size distribution and histological typing of the 25 'asymptomatic' peripheral tumours are given to the right of the vertical axis in Figure 1. Their average size was $4.5 \pm 1.8 \mathrm{~cm}$., which is intermediate between that of the central tumours and that of the 'symptomatic' peripheral tumours. There were no asymptomatic central tumours.

\section{RATE OF TUMOUR GROWTH}

Information about the rate of growth of primary carcinoma of the lung has been derived from serial chest radiographs by Spratt, Spjut, and Roper (1963), and an average rate for each histological type has been ascertained (Table III). The accuracy of models of tumour growth has been examined by Mendelsohn (1963), and it seems likely that the increase in diameter lies between that calculated from a linear rate of growth and that calculated from an exponential rate. We have worked out various time relations concerning lung tumours, using the information supplied by the above authors' linear and exponential growth models and the data given earlier in this paper. As these authors use a classification of squamous carcinoma, adenocarcinoma, and undifferentiated 
T A B L E I

DIAMETER OF TUMOURS (CM.) WITH STANDARD DEVIATIONS

\begin{tabular}{|c|c|c|c|}
\hline & $\begin{array}{c}\text { Peripheral } \\
\text { Tumours }\end{array}$ & $\begin{array}{c}\text { Central } \\
\text { Tumours }\end{array}$ & Difference \\
\hline $\begin{array}{l}150 \text { tumours } \\
85 \text { peripheral } \\
65 \text { central }\end{array}$ & $6 \cdot 4 \pm 2 \cdot 5$ & $3 \cdot 4 \pm 1 \cdot 4$ & $3.0 \pm 0.3(P=0.001-0.01)$ \\
\hline $\begin{array}{l}\text { Squamous tumours } \\
34 \text { peripheral } \\
50 \text { central }\end{array}$ & $6 \cdot 9 \pm 2 \cdot 2$ & $3 \cdot 3 \pm 1 \cdot 3$ & $3.6 \pm 0.4(P=0.001)$ \\
\hline $\begin{array}{l}\text { Oat-cell tumours } \\
11 \text { peripheral } \\
13 \text { central }\end{array}$ & $6 \cdot 2 \pm 2 \cdot 7$ & $4 \cdot 0 \pm 4 \cdot 7$ & $2 \cdot 2 \pm 1 \cdot 5(\mathrm{P}=0 \cdot 10-0 \cdot 20)$ \\
\hline $\begin{array}{l}\text { Adenocarcinomata } \\
25 \text { peripheral } \\
0 \text { central }\end{array}$ & $6 \cdot 1 \pm 2 \cdot 4$ & - & - \\
\hline $\begin{array}{l}\text { Polygonal tumours } \\
15 \text { polygonal } \\
2 \text { central }\end{array}$ & $6 \cdot 0 \pm 3 \cdot 1$ & - & 一 \\
\hline
\end{tabular}

The close grouping of the peripheral tumours around $6 \mathrm{~cm}$. and of the central tumours around $3.5 \mathrm{~cm}$. is evident, as is the marked difference in size between the peripheral group and the central group.

T A B L E I I

LENGTH OF HISTORY (MONTHS) WITH STANDARD DEVIATIONS

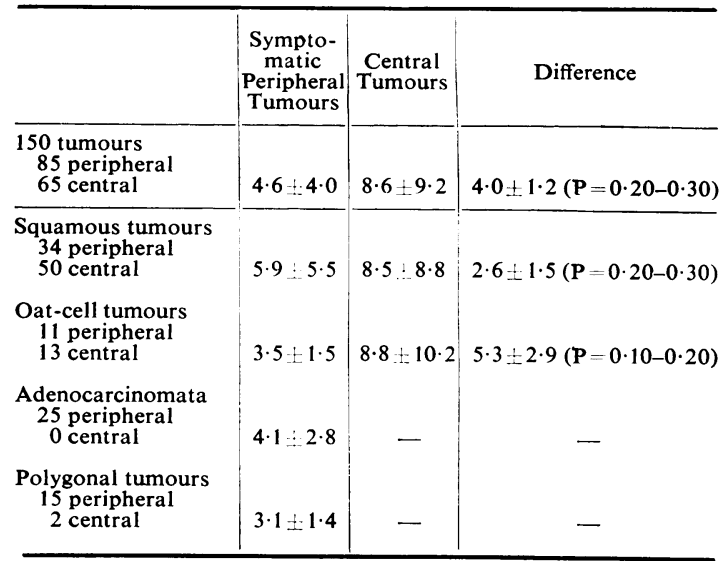

There is grouping of the central tumour histories around 8.5 months and of peripheral tumour histories around 4 months, but owing to the large individual variation the difference is not significant.

T A B L E I I I

GROWTH RATES (FROM SPRATT ET AL.)

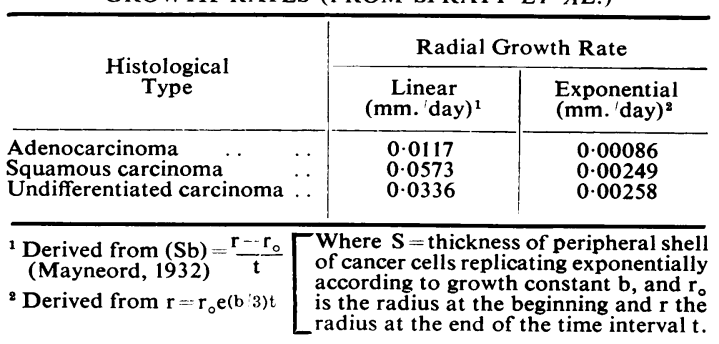

carcinoma, we have had to use the 'undifferen- $\frac{\bar{D}}{\overline{0}}$ tiated carcinoma' data for our polygonal and oat- $\overline{\bar{\omega}}$. cell tumours. For convenience, the times are given $\mathbb{\otimes}$ as months (one month being 28 days).

The measured diameter of tumours at operation and the calculated diameter at the onset of $\vec{\circ}$ symptoms are given in Table IV, from which it is

TABLE IV

CALCULATION OF DIAMETER OF TUMOUR AT WHICH SYMPTOMS MUST HAVE ARISEN

\begin{tabular}{|c|c|c|c|c|}
\hline & \multirow{2}{*}{$\begin{array}{c}\text { Operation } \\
\text { Diameter } \\
(\mathrm{cm} .)\end{array}$} & \multirow{2}{*}{$\begin{array}{c}\text { Symp- } \\
\text { toms } \\
\text { (months) }\end{array}$} & \multicolumn{2}{|c|}{$\begin{array}{c}\text { 'Symptom Diameter' } \\
\text { (cm.) (using data of } \\
\text { Spratt } \text { et al.) }\end{array}$} \\
\hline & & & $\underset{\substack{\text { Linear } \\
\text { Rate }}}{\text { At }}$ & $\begin{array}{l}\text { At Expo- } \\
\text { nential } \\
\text { Rate }\end{array}$ \\
\hline $\begin{array}{cc}85 \text { peripheral } \\
\begin{array}{c}\text { carcinomata } \\
25 \text { adeno- }\end{array} \\
11 \text { oat-cell } & \ldots \\
34 \text { squamous } & \ldots \\
15 \text { polygonal } & \ldots\end{array}$ & $\begin{array}{l}6 \cdot 1 \\
6 \cdot 2 \\
6 \cdot 9 \\
6 \cdot 0\end{array}$ & $\begin{array}{l}4 \cdot 1 \\
3 \cdot 5 \\
5 \cdot 9 \\
3 \cdot 1\end{array}$ & $\begin{array}{l}5 \cdot 9 \\
5 \cdot 6 \\
5 \cdot 0 \\
5 \cdot 4\end{array}$ & $\begin{array}{l}5 \cdot 5 \\
4 \cdot 8 \\
4 \cdot 5 \\
4 \cdot 8\end{array}$ \\
\hline $\begin{array}{c}3 \text { central carcino- } \\
\text { mata } \\
\begin{array}{ll}13 \text { oat-cell } & \\
50 \text { squamous } & \ldots\end{array}\end{array}$ & $\begin{array}{l}4 \cdot 0 \\
3 \cdot 3\end{array}$ & $\begin{array}{l}8 \cdot 8 \\
8 \cdot 5\end{array}$ & $\begin{array}{l}2 \cdot 3 \\
0 \cdot 6\end{array}$ & $\begin{array}{l}2 \cdot 1 \\
1 \cdot 8\end{array}$ \\
\hline $\begin{array}{cc}25 \text { asymptomatic } \\
\text { peripheral } \\
\text { carcinomata } \\
10 \text { adeno- } \\
5 \text { oat-cell } & . . \\
6 \text { squamous } & . . \\
4 \text { polygonal } & . .\end{array}$ & $\begin{array}{l}4 \cdot 8 \\
3.9 \\
4 \cdot 2 \\
4 \cdot 8\end{array}$ & & & \\
\hline $\begin{array}{l}85 \text { peripheral car- } \\
\text { cinomata with } \\
\text { symptoms (mean) }\end{array}$ & 6.4 & & $5 \cdot 4$ & 4.9 \\
\hline $\begin{array}{l}63 \text { central carcino- } \\
\text { mata with symp- } \\
\text { toms (mean) }\end{array}$ & $3 \cdot 4$ & & 0.9 & 1.9 \\
\hline $\begin{array}{l}25 \text { asymptomatic } \\
\text { peripheral carcino- } \\
\text { mata (mean) }\end{array}$ & $4 \cdot 5$ & & & \\
\hline
\end{tabular}

seen that central tumours produce symptoms at 0.6 to $2.3 \mathrm{~cm}$. diameter, whereas peripheral tumours produce symptoms at 4.5 to $5.9 \mathrm{~cm}$. In o our series asymptomatic peripheral tumours were resected at an average size of $4.5 \mathrm{~cm}$. diameter.

The difference in size between the symptomatic peripheral tumours and the central tumours was $\tilde{N}$ used to calculate how much 'older' the peripheral $N$ tumours were at operation (Table V). We chose N a diameter of $0.6 \mathrm{~cm}$. as being a size of tumour which is within the range in which growth data are available and which is also readily discernible $\stackrel{\circ}{\square}$ in the peripheral lung fields on radiography. The time taken for both central and peripheral types of tumour to grow from $0.6 \mathrm{~cm}$. diameter to the size found at operation was calculated. These $\vec{D}$ results are also given in Table V. It is clear from $\stackrel{\stackrel{P}{\mathbb{D}}}{\circ}$ this Table that a peripheral carcinoma is on aver- $\varrho$ age six to 11 months 'older' than a central 
TABLE V

MONTHS FROM $0.6 \mathrm{CM}$. DIAMETER TO SIZE AT OPERATION (using data of Spratt $e t$ al. for growth rates)

\begin{tabular}{|c|c|c|c|c|}
\hline & $\begin{array}{c}\text { Sympto- } \\
\text { matic } \\
\text { Peripheral }\end{array}$ & $\begin{array}{l}\text { Asympto- } \\
\text { matic } \\
\text { Peripheral }\end{array}$ & Central & $\begin{array}{l}\text { Difference } \\
\text { (S.P.-C.) }\end{array}$ \\
\hline $\begin{array}{c}\text { Squamous carcinoma } \\
\text { Assuming linear } \\
\text { rate of growth } \\
\text { Assuming expo- } \\
\text { nential rate of } \\
\text { growth }\end{array}$ & $\begin{array}{l}19 \cdot 5 \\
35\end{array}$ & $\begin{array}{l}11 \\
28\end{array}$ & $\begin{array}{r}8 \cdot 5 \\
24 \cdot 5\end{array}$ & $\begin{array}{l}11 \\
10 \cdot 5\end{array}$ \\
\hline $\begin{array}{l}\text { Oat-cell carcinoma } \\
\text { Linear } \\
\text { Exponential }\end{array}$ & $\begin{array}{l}30 \\
32\end{array}$ & $\begin{array}{l}17 \\
26\end{array}$ & $\begin{array}{l}18 \\
26\end{array}$ & $\begin{array}{r}12 \\
6\end{array}$ \\
\hline $\begin{array}{ll}\text { Adenocarcinoma } \\
\text { Linear } \\
\text { Exponential } & \ldots\end{array}$ & $\begin{array}{l}84 \\
96\end{array}$ & $\begin{array}{l}64 \\
86\end{array}$ & & \\
\hline $\begin{array}{c}\text { Polygonal carcinoma } \\
\text { Linear } \because \\
\text { Exponential }\end{array}$ & $\begin{array}{l}29 \\
32\end{array}$ & $\begin{array}{l}22 \\
29\end{array}$ & & \\
\hline
\end{tabular}

carcinoma. It is also apparent that a symptomatic peripheral tumour at operation has been detectable on a chest radiograph for more than 19 months if it is a squamous, oat-cell, or polygonal carcinoma, and for more than 64 months if it is an adenocarcinoma. Even the asymptomatic peripheral tumours, often called 'early', would have been visible for more than 11 months.

It is possible to speculate on the total duration of a carcinoma (from a size of one cell of $25 \mu$ diameter to the size at operation). As there is no information available on the growth of lung tumours below $0.6 \mathrm{~cm}$. diameter, the rate of growth of larger tumours must be extrapolated and cannot be taken as reliable, though it gives some idea of the long time involved. These speculations are given in Table VI.

\section{T A B L E V I}

TOTAL DURATION (MONTHS) OF 110 PERIPHERAL AND 65 CENTRAL LUNG CARCINOMATA (using data of Spratt $e t$ al. for growth rates)

\begin{tabular}{|c|c|c|c|c|c|}
\hline & & & & Linear & Exponential \\
\hline $\begin{array}{l}\text { Squamous carcin } \\
\text { Central } \\
\text { Peripheral }\end{array}$ & $\begin{array}{c}m a \\
\cdots \\
\cdots\end{array}$ & $\because$ & $\because$. & $\begin{array}{l}10 \\
20\end{array}$ & $\begin{array}{l}103 \\
113 \\
\end{array}$ \\
\hline $\begin{array}{l}\text { Undifferentiated } \\
\text { Central } \\
\text { Peripherai }\end{array}$ & $\begin{array}{l}\text { carc } \\
\ldots \\
. .\end{array}$ & $\begin{array}{l}\text { na } \\
\cdots \\
\cdots\end{array}$ & $\because$ & $\begin{array}{l}21 \\
29\end{array}$ & $\begin{array}{l}102 \\
106\end{array}$ \\
\hline $\begin{array}{l}\text { Adenocarcinoma } \\
\text { Peripheral }\end{array}$ & . & . & . & 87 & 320 \\
\hline
\end{tabular}

\section{DISCUSSION}

Bignall (1958) considered that there was no difference in the length of history between central and peripheral tumours, that 'Peripheral tumours are likely to be older than central ones when they are discovered; but there is no evidence that they cause longer illnesses once symptoms have appeared'. The present results show that on average the length of history is longer for the central tumours. Their histories are longer despite the more urgent character of the symptoms which would tend to bring them more quickly under medical care. The reason for this contradiction is that although a definite histological diagnosis is more feasible with central tumours a presumptive radiological diagnosis is much more readily made with peripheral tumours. Peripheral tumours generally occur in the radiotranslucent lung fields and are also easier to diagnose because they are larger. But, as is evident in Fig. 1, pre-operative delays are common with peripheral tumours, presumably due to the neglect of early symptoms on account of their mild character. It is therefore not surprising that the difference in the length of history should not be statistically significant.

The difference in tumour size has statistical significance. The explanation for this is twofold: (1) Peripheral tumours have a higher operative ceiling than central tumours. Due to their proximity to the mediastinum, central tumours become inoperable on account of their size at about $6 \mathrm{~cm}$. Peripheral tumours, on the other hand, often remain operable till twice this size; nearly half the resected peripheral tumours were above the operative limit of the central tumours. (2) Central tumours have an earlier onset of symptoms. The central tumours are even smaller than the 25 peripheral tumours which had not yet developed symptoms $(3.4$ and $4.5 \mathrm{~cm}$.).

The earlier onset of symptoms with central tumours is shown diagrammatically in Figs 3 and 4 , in which the calculated sizes of the individual tumours at the onset of symptoms are superimposed on the growth curves for lung tumours constructed from the radiological observations of Spratt $e t$ al. On account of the accidental occurrence of haemorrhage, necrosis, ulceration, and cavity distension, the actual rate of growth varies much more than these diagrams suggest ; they are average curves made on the assumption that tumours of the same histological type grow at the same rate whether central or peripheral. It will be seen from the diagrams that on the average symptoms begin about a year earlier with the central tumours than with the peripheral tumours (a little more than a year with the squamous and a little less with the oat-cell tumours). There is little difference between the two histological types in this respect. Symptoms begin on the average at about 


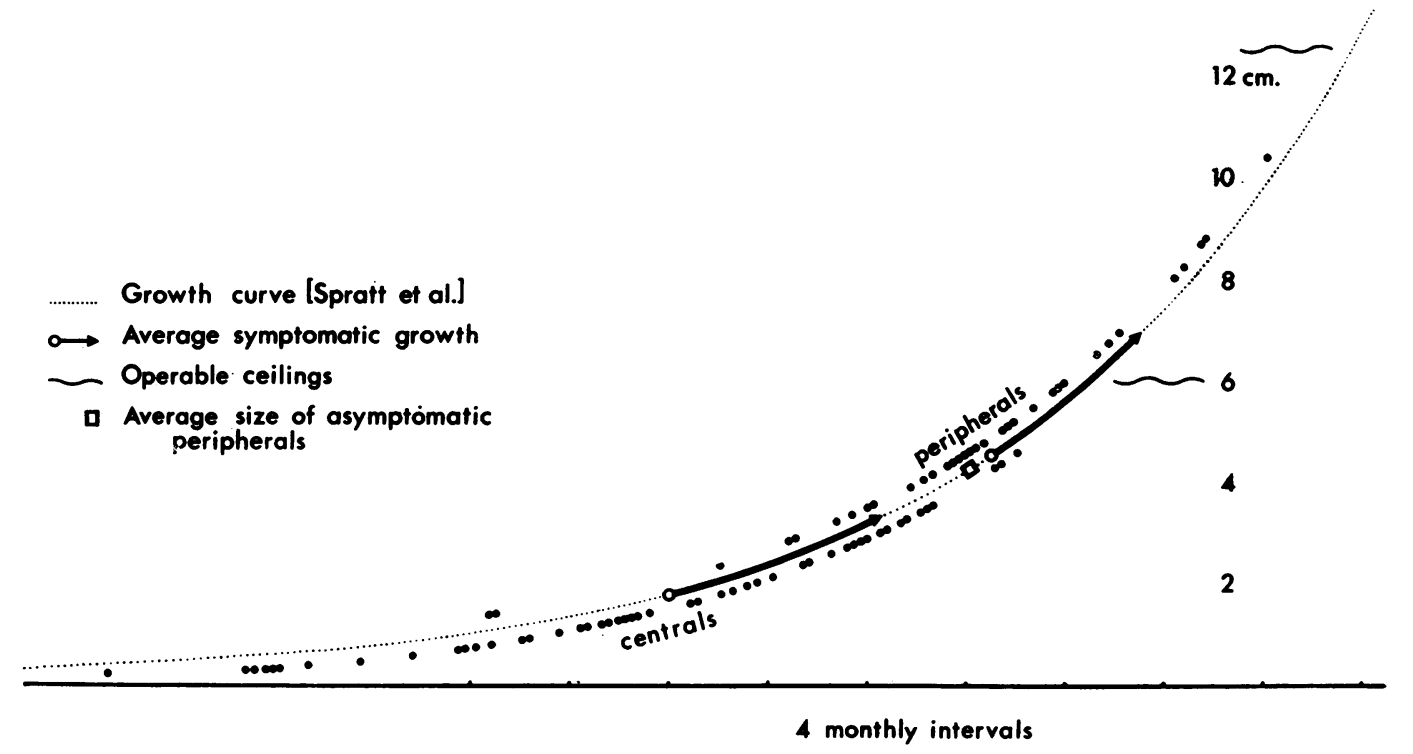

FIG. 3. Size of squamous tumours at onset of symptoms. One of the central tumours was $5 \mathrm{~cm}$. in diameter at resection and hat a history of five years. It is therefore not included in this figure.

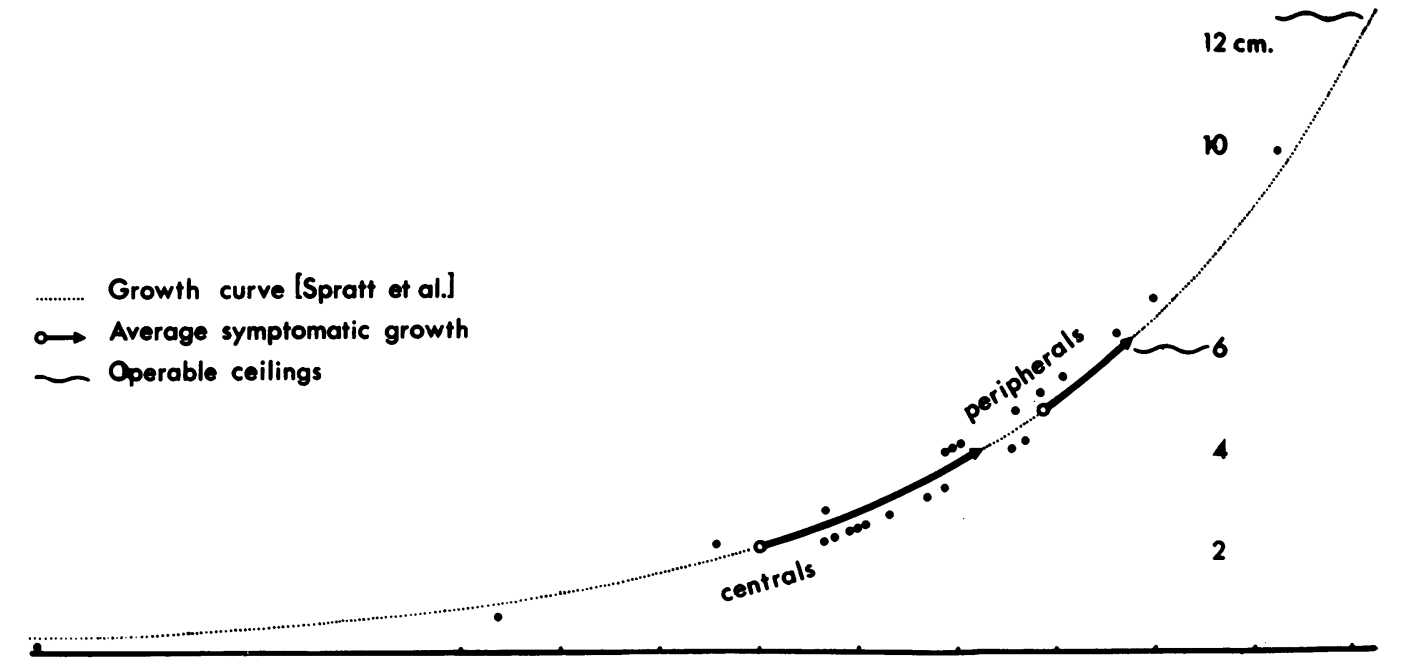

4 monthly intervals

FIG. 4. Size of oat-cell tumours at onset of symptoms.

$2 \mathrm{~cm}$. with the central tumours and at about 4.5 $\mathrm{cm}$. with the peripheral tumours, whether they are oat-cell or squamous. The difference in size between central and peripheral tumours remains large even when the peripheral tumours above $6 \mathrm{~cm}$. are excluded from the comparison $(2 \mathrm{~cm}$. and $3.5 \mathrm{~cm}$.). This means, of course, that the earlier onset of symptoms with central tumours is 
not something peculiar to surgical cases but has a more general application. Adenocarcinomata are rare as central tumours, so that a comparison between central and peripheral cases is not possible. According to Spratt et al., their rate of growth is slow (a volume doubling time of 269 days compared with 90 days for oat-cell and 93 days for squamous-cell tumours).

It is mistaken to think too much in terms of average size and to neglect the individual variation within the tumour groups, which is very large. Thus, with the peripheral squamous tumours the size at onset of symptoms varies from $1 \mathrm{~cm}$. to $10 \mathrm{~cm}$., and with the central squamous tumours from less than $0.25 \mathrm{~cm}$. to $4 \mathrm{~cm}$. Similar variations are evident with the oat-cell groups. The fortuitous factor mainly responsible for these large differences in size (corresponding with differences in time of the order of several years) is probably infection. This would make the onset of symptoms a matter of chance and also explain the earlier onset of symptoms with central tumours. Symptoms associated with infection tend to occur earlier with central tumours because they are nearer the source of infection (in the pharynx), and because infection occurs more readily in the presence of obstruction. The earlier onset of symptoms with central tumours is unlikely to be due to other fortuitous factors, such as necrosis, because these would affect central and : peripheral tumours equally.

The anatomical evidence of infection with central tumours is the familiar picture of retention bronchiectasis with obstructive pneumonitis which may go on to multiple abscess formation, ulceration of the ectatic bronchi, and fibrotic shrinkage ; with central tumours this is often seen when the tumour is still small. Obstructive pneumonitis also occurs with peripheral tumours but only in the later stages of the disease when the tumour has encroached on the hilum or produced hilar metastases. Most peripheral tumours, however, are resected at an earlier stage than this. In them, definite evidence of acute inflammation is rare, even when there is a history suggestive of pneumonitis and pleurisy. Very occasionally, however, about peripheral tumours even of small size one sees a yellow halo of lipoid pneumonitis suggestive of a former acute process. The possibility of infection is still more evident with cavitation. Probably these infections are intermittent and often of a low-grade character (as is clearly the case in obstructive pneumonitis). We thought it possible that the onset of symptoms would be accelerated in cases with chronic bronchitis because, as Brumfitt, Willoughby, and Bromley (1957) have shown, the bronchial tree in this condition is no longer sterile. Evidence for this is provided by the asymptomatic group. The incidence of chronic bronchitis was similar to that in the symptomatic group (32\% and $28 \%$ ). There was, however, only one case with chronic bronchitis among the 15 with tumours above $4 \mathrm{~cm}$. diameter, compared with five among the 10 cases with tumours up to this size. In spite of its current interest it was not possible from the notes to make an analysis with regard to smoking.

Segmental air distension beyond a partial block also affects central tumours earlier than peripheral tumours. With peripheral tumours this condition can occur only when the tumour has grown large enough to involve the hilar bronchi; with central tumours it is a possibility even when the tumour is smaller than an intermediate bronchus. The condition is radiological and usually temporary, although it can affect several bronchi in succession. It can occur in the absence of infection, but in these circumstances the transient symptoms of dyspnoea and discomfort could easily be forgotten.

The asymptomatic tumours in the present series of cases were all peripheral. Their average size, with all four histological types, was rather less than the estimated size at the onset of symptoms (Table IV). The apparent rarity of asymptomatic central tumours in resected specimens is largely due to the earlier onset of symptoms. It should be noted, however, that some of the largest central tumours had been symptomatic for only a short time; had the development of symptoms been delayed a little longer, these cases would have become inoperable. It seems probable that some central tumours without symptoms are being overlooked in radiological surveys due to the greater difficulty in recognizing them. The anatomical appearances of asymptomatic central tumours are those of sterile bronchial obstruction: the bronchi beyond the growth are distended with clear mucus which extends into the lung and re-expands the collapsed acini (mucus consolidation). It is rare to see this condition by itself, but as a localized condition affecting a segment of a lobe which elsewhere shows gross obstructive pneumonitis it is not uncommon ; as pointed out by Walter and Pryce (1955b), it can provide a clue to the bronchus in which obstruction first occurred.

The surgical origin of the material accounts for some of the results, e.g., the relatively small proportion of oat-cell tumours and the absence of any oat-cell tumours among the peripheral group with a history longer than six months. The main 
theme of this paper, however, that central tumours tend to develop symptoms earlier than peripheral tumours, probably applies to lung tumours in general.

\section{SUMMARY}

Most presenting symptoms are more frequent with central tumours (cough $48 \%$ compared with $35 \%$; haemoptysis $29 \%$ compared with $22 \%$; fever $28 \%$ compared with $22 \%$; dyspnoea $23 \%$ compared with $7 \%$; but pain $23 \%$ compared with $36 \%)$. The average pre-operative history, however, is longer with central tumours $(8.6$ months compared with 4.6 months) due to greater difficulty in diagnosis. The smaller size of central tumours $(3.4 \mathrm{~cm}$. diameter compared with $6.4 \mathrm{~cm}$. diameter) is partly due to the longer operability of peripheral tumours and the earlier onset of symptoms with central tumours (about one year earlier with both oat and squamous tumours). The onset of symptoms is mainly associated with chance infection, which accounts for the great variation in time. Infection occurs more easily with obstruction, which is more characteristic of central tumours. Of the 25 asymptomatic tumours (all peripheral) there was only one with chronic bronchitis among the 15 tumours above $4 \mathrm{~cm}$. diameter compared with 5 among the 10 tumours below this size. It seems unlikely that any tumour can become large and remain asymptomatic when associated with chronic bronchitis. Adenocarcinomata are said to be slow growing, but as most are peripheral resected specimens are often large.

We are indebted to Dr. Eugen Nassau, consultant $\vec{\circ}$ pathologist, Harefield Hospital, whose co-operation made this investigation possible. Our thanks are also $\vec{\omega}$ due to the many medical officers who provided the $O$ specimens, especially to Sir Thomas Holmes Sellors $\frac{\vec{x}}{x}$ and Mr. Lance Bromley. We are grateful to Mrs. i Ethne Green (née Murphy) for technical assistance and to Miss Joan Mahoney, who made the statistical calculations under the direction of Dr. Lewis Holt.

This work was supported by a grant from the British Empire Cancer Campaign.

\section{REFERENCES}

Bignall, J. R. (1958). The course of carcinoma of the lung. In Monographs on Neoplastic Disease at Various Sites. General ed. D. W. Smithers, vol. 1. Carcinoma of the Lung, ed. J. R. Bignall, (1) p. 189. Livingstone, Edinburgh and London.

Brumfitt, W., Willoughby, M. L. N., and Bromley, L. L. (1957). An evaluation of sputum examination in chronic bronchitis. Lancet, 2,1306 .

Mayneord, W. V. (1932). On a law of growth of Jensen's rat sarcoma. Amer. J. Cancer, 16, 841

Mendelsohn, M. L. (1963). Cell proliferation and tumor growth. In Cell Proliferation. A Guinness Symposium held at University of Dublin, Trinity College, p. 190. Ed. L. F. Lamerton and R. J. M. Fry. Blackwell, Oxford.

Spratt, J. S., Jr., Spjut, H. J., and Roper, C. L. (1963). The frequency distribution of the rates of growth and the estimated duration of primary pulmonary carcinomas. Cancer, 16, 687 .

Walter, J. B., and Pryce, D. M. (1955a). The histology of lung cancer Thorax, 10, 107 .

- $1955 \mathrm{~b})$. The site of origin of lung cancer and its relation to histological type. Ibid, $10,117$. 